\title{
Changes in the Utilization of the Proto-Historical Landscape, Soppeng Regency, Indonesia
}

\author{
Muhammad Nur ${ }^{*}$, Akin Duli², Yusriana ${ }^{3}$ \\ ${ }^{1,2,3}$ Department of Archaeology, Faculty of Cultural Sciences, Universitas Hasanuddin \\ *Corresponding author. Email: mnur@unhas.ac.id
}

\begin{abstract}
This research discusses the transition of the utilization of the landscape of the Proto-historic Soppeng Kingdom. In this discussion, Sewo as a megalith site is the focus because from this site the buffer villages of the 14th century Soppeng kingdom originated. The methods used are archaeological, ethnographic, and historical methods. The results showed that there was a change in landscape utilization patterns from hilly areas to sloping lowland areas. The first phase of settlement was a settlement on a hilly area, took place in the 12th/13th century, then turned into a lowland settlement suitable for rice fields. The change in landscape usage patterns was caused by the decision to turn agricultural livelihoods into systematic rice farming livelihoods. The decision to manage systematic rice farming in the 14th century was consequent to the rice surplus which then triggered the unification of farmers' villages into the Kingdom of Soppeng. This article will add to our understanding of the dynamics of proto-historical culture in Indonesia, especially on landscape utilization patterns.
\end{abstract}

Keywords: Sewo, Megalith, landscaping, Soppeng

\section{INTRODUCTION}

During increasingly vociferous changing times, sewo megalith complex which is the location of ancient rituals survives to this day. When rituals take place led by a sanro (Bugis language meaning shaman),people bring a variety of food. Not infrequently, rituals are coloured by the slaughter of chickens, goats, or buffalo as sacrifices. Under the large banal tree that the community is greatly sacred to, sanro recited prayer sentences in ancient Bugis language that the Bugis are already elusive to the Bugis today. The ritual organizers are rice farmers and farmers.

Sewo megalith complex is still original, not much damage compared to similar sites in Indonesia and is very guarded by the local community. This megalith complex is located in the interior, at an altitude of 325-417 meters above sea level which is administratively included in Bila Village, Lalabata Subdistrict, Soppeng Regency, South Sulawesi Province. In the context of the local history of South Sulawesi, the position of Sewo toponim is important because it is the location of the origin of the population of the kingdom of Soppeng Riaja (West Soppeng) Kallupa, [1]. In the local manuscript, it is also told that sewo settlers spread down hilly topography leading to lowland settlement land. The post-piping settlers then experienced a surplus of rice and then unification into the 14th century Kingdom of Soppeng Riaja based in Tinco Tua. The short story footage of Sewo's toponim exudes a past community mindset about changing landscape utilization from hilly landscaping to potential lowland landscaping for agriculture. We chose to discuss Sewo megaliths in this forum because of the importance of this megalith complex in the history of landscape utilization in the past, both within the scope of South Sulawesi and Indonesia. Thus, the results of this study can be a reference to uncovering past aspects of similar megalith complexes in other cultural regions. The details of the material to be discussed are the importance of this megalith complex in the history of the Kingdom of Soppeng, especially about the history of landscape utilization during the proto-history in South Sulawesi. This article will add to our understanding of the dynamics of proto-historical culture in Indonesia. 


\section{METHODS}

From 2019 to 2021, we have researched nine Soppeng royal buffer sites. The working order is a reading of local chronicles as well as systematic surveys with a focus on observations on archaeological artifacts (megalithic monuments and ceramic fragments) and environmental variables especially at height, distance, marbles, and soil type. Interviews are conducted to corroborate environmental information and archaeological information. At the analysis stage, it is determined the authenticity, shape, function, and distribution of findings. Analysis of environmental variables is carried out on determining soil type, distance from rivers, altitude, and marbles. All the findings that have been analyzed separately are then put together to confirm each other. Finally, the details of the material discussed can be revealed, especially related to the transition of landscape use since the period of occupancy on the ridge as evidenced by the Sewo site until the unification of toponim-toponim formed the kingdom of Soppeng Riaja in the 14th century. In the end, we attributed the transition of the utilization of the Soppeng kingdom landscape in the context of the local history of South Sulawesi.

\section{DESCRIPTION AND ANALYSIS}

Soppeng Regency is bordered by Sidenreng Rappang Regency in the north, Bone and Wajo regencies in the east, Bone Regency in the south and Barru Regency to the west. The height of the area is between 20 meters to 2,000 meters above sea level, with rice fields covering an area of 40,000 hectares, forest area of 60,000 hectares, gardens covering an area of 48,000 hectares, and rivers covering an area of 640 hectares. The topographic conditions of the Soppeng Regency region are weakly surging in the middle, while in the south and west the wavy is medium and strong, which is a forest area. In the north and east, the topography tends to be flat, most of which people process into rice fields, plantations and settlements. Its people belong to the Bugis ethnic group, the largest on the island of Sulawesi and one of the ethnic groups with a large population in Indonesia. The Soppeng people speak the Bugis language, which is one variant of the Austronesian language family [2].

There are two ground level reliefs in Soppeng Regency, namely the relief of hills and plains areas. The area of the hills is $800 \mathrm{~km}$ which is at an altitude of about 00 meters above sea level, while the area of the plains is about $700 \mathrm{~km}$ which is between 10-200 meters above sea level. The mountain in Soppeng is not too high. The highest mountain is Mount Nenek
Conang with an altitude of $1,463 \mathrm{~m}(\mathrm{dpl})$, while the other mountains are Mount Sewo with an altitude of $860 \mathrm{~m}$ (dpl), Mount Lapancu with an altitude of 850 $\mathrm{m}$ (dpl), Mount Buludua with an altitude of $800 \mathrm{~m}$ (dpl) and Mount Paowengeng with an altitude of 760 $\mathrm{m}$ (dpl). There are six main rivers in Soppeng Regency, flowing spread across farmland. The six main rivers are the Lawo River, Soppeng River, Walennae River, Paddangeng River, Langkemme River, and Lajaroko River.

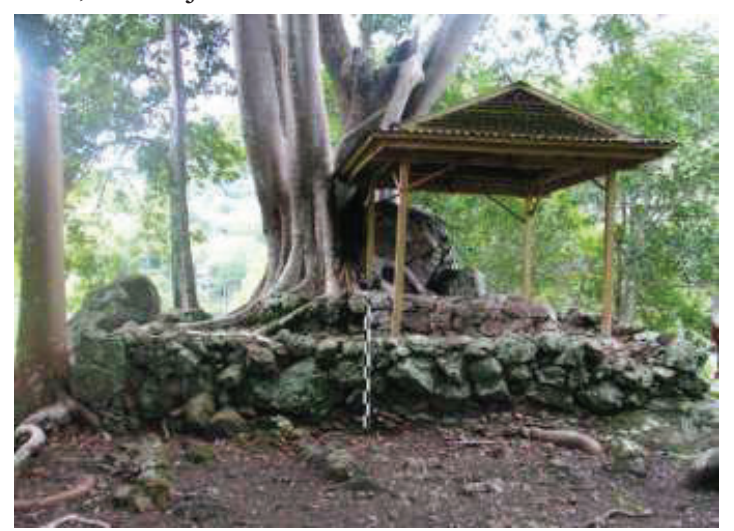

Figure 1. The cult centrum at the top of sewo's megalith.

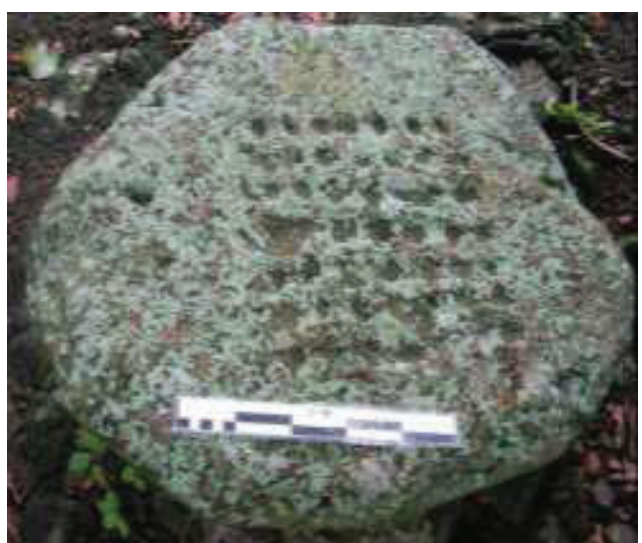

Figure 2. Dakon stone with the number of holes 49, played by shamans to determine the good time of agricultural activities.

Local people refer to the location of sewo megaliths as Petta Allangkanange hill whose peak is only $60 \times 50$ meters. At the foot of the allangkanange hill whose surface is relatively flat, there are findings such as stone lumpang, arrangement of bracelets, dakon stones, pottery shards, metal objects and foreign ceramics scattered, which is evidence of intensive occupancy since the pre-royal period of Soppeng. A systematic survey by a joint Indonesian Australian team led by Kallupa [1] produced a range of ceramic dates between the 12th and 17 th centuries. 
In Bugis, allangkanange means the place of the king's palace. The top of the allangkanange hill is surrounded by a rectangular terrace structure, inside which there are worship stones, stone tables, dakon, tray stones, stone stairs, and altar stones in a functional tangle. Massorong is the name of the ritual in this place, the purpose of its implementation is to release vows related to agricultural activities. In the procession, various colours of glutinous rice (sokko patanrupa), cakes, coconuts, bananas, eggs, and poured water are presented as a tribute to De'watang Seuwae (the single God). In the attoriolonna soppenglontarak, it is narrated that the people of Soppeng come from two places, namely Sewo and Gattareng. People from Sewo down occupy an area called Soppeng Riaja (West Soppeng), including Pesse, Seppang, Pising, Launga, Mattabulu, Ara, Lisu, Lawo, Madello Rilau and Tinco. Sewo's story in the historical trajectory of Soppeng is the period that preceded the emergence of Latemmamala (Tomanurung) in Sekkanyili, which later became the first Soppeng king in the early 14th century.

In addition to the Sewo site, we have also conducted archaeological surveys on eight toponym written in the chronicles of Attoriolonna Soppeng, namely the sites tinco, lawo, laleng fort, bila, sekkanyili, ujung, pising, and botto. In general, the eight sites are on a flat topography with no meaningful hills. The expanse of rice fields is a characteristic of the landscape of the eight sites. The livelihoods of its people are mostly rice farmers with irrigation rice fields. The marbles of the eight sites are $2-13 \%$, illustrating their sloping topography. The eight sites are also at varying heights but are all below 200 meters from sea level, except the Sewo site. To see the difference in height between the Sewo megalith complex and other sites, the table is outlined as follows.

\begin{tabular}{|l|l|c|c|}
\hline No. & \multicolumn{1}{|c|}{ Site name } & $\begin{array}{c}\text { Height } \\
(\mathrm{mdpl})\end{array}$ & $\begin{array}{c}\text { Marbles } \\
(\%)\end{array}$ \\
\hline 1. & Sewo & $325-417$ & 32,2 \\
\hline 2. & Tinco & $99-133$ & 5,6 \\
\hline 3. & Lawo & $145-176$ & 2,7 \\
\hline 4 & Bila & $125-137$ & 7,0 \\
\hline 5. & Pising & $41-59$ & 5,9 \\
\hline 6. & Sekkanyili & $23-29$ & 3,0 \\
\hline 7. & $\begin{array}{l}\text { Laleng } \\
\text { Benteng }\end{array}$ & $102-123$ & 13,1 \\
\hline 8 & Ujung & $100-120$ & 6,6 \\
\hline 9 & Botto & $111-121$ & 5,0 \\
\hline
\end{tabular}

Based on the map of Tanah Tindjau Of South Sulawesi Province (1968), there are several types of soil in Soppeng, namely 1) KMC is a brownRegosol-Liosol mediteran complex, 2) KMCL is a brown and litosol mediteran complex, 3) LTS is lithuanian, 4) $\mathrm{MC}$ is a brown mediteran complex, 5) MCK1 is a grayish brown regosol, 6) MCKm is a reddish-brown mediterant, 7) $\mathrm{RegC}$ is a brown regosol, and 8) RegCK is a grey-brown regosol. The nine archaeological sites mentioned in table 1 above are on the ground of the brown-Regosol-Liosol (KMC) mediteran complex. This type of soil according to the simplified classification system is mediteran which later turns into Alfisol. Alfisol is fertile soil, where most agricultural activities take place [3]; [4]. This data illustrates a very strong correlation between the distribution of the site and the type of soil. When associated with the dominant subsistence pattern carried out at the time of the emergence of the Kingdom of Soppeng, then the information can be used to claim that the selection of village locations strictly considers the soil conditions suitable for wet rice farming areas.

Except for the Sewo site, the eight sites in table 1 are on land close to the river. The river contained at the Sewo site is seasonal, will be filled with water if the rainy season and when the dry season will be mongering. At eight other sites, the river is only a few hundred meters away from the site' location. This data illustrates that the selection of settlement locations in the 14th century strongly considers the existence of rivers near settlements and ancient rice fields.

There are six types of rocks found in Soppeng Regency, namely 1) Alluvium and coastal deposits, 2) Tacipi members of walennae formations: limestone 3) Walennae formations: sandstone, siltstone, tufa, napal, clay, conglomerate and limestone, 4) Soppeng volcano rocks: breaksi and lava, 5) Camba volcano rocks: breccia, lava, tufa and conglomerates, and 6) Tonasa Formation: limestone. Our survey results showed that only the Sewo site on the soppeng volcanic rock area is characterized by breaksi and lava. Eight other sites are on an area with alluvium and coastal sedimentary rocks.

\section{DISCUSSION}

The geography picture above gives information that there is a difference in geographical variables between sewo sites and eight sites or buffer toponim of the 14th century Kingdom of Soppeng. Information from the lontarak attoriolonna soppeng manuscript mentions that Sewo is the location of the origin of the Soppeng people who descended into the lowlands. This is the focus of our discussion on this 
article. There are several questions related to this discussion, namely when the Sewo settlement began, when sewo settlers spread, what is the reason for the movement of Sewo settlers from hilly locations to flat land, and how the impact of this analysis results in the context of the local history of South Sulawesi.

The most effective artifacts and do not require laboratory analysis to confirm Lontarak attoriolonna Soppeng are imported ceramic scatter and dated data. There are several surveys of imported ceramic fragments from archaeological sites in Soppeng [5]; [1], included in this study. Sewo site import ceramic shards include 12th/13th century Sung stoneware and 13th/14th century Yuan Celadon, 15th/16th century Ming Celadon, 17th century Swatow, 16th/17th century blue and white blue Kang-Hsi, 17th/18th century Blue And White Kang-Hsi. The total number of imported ceramic fragments from the Sewo site is 211 and after analysis shows that the site was inhabited in the 12 th/13th to 17 th centuries and abandoned in the 18th century [1].

The results of analysis of ceramic fragments imported sewo site after confirmed with Lontarak attoriolonna Soppeng information that sewo site is not suddenly abandoned but the population grows and then spread to various wanuwa in Soppeng Riaja. Episodes of the settler spread of the Tinco site written in local chronicles also still exist in the collective memory of the Soppeng people. Recording this story in local chronicles and still attached to the collective memory of the community shows how important this episode is to the people of Soppeng.

The main point of the spread episode is the geographical character that sewo settlers were referring to. Our survey of eight important 14thcentury sites in Soppeng (table 1) shows the distinct geographical character of the Sewo site. The intended landscape is flat land with marbles between $2.7 \%$ $13.1 \%$, much different from the Sewo site which has a marble of $32.2 \%$. In addition, the height position of the eight sites is between 23-29 mdpl to 145-176 mdpl, much different from the Sewo site which is at an altitude of 325-417. Another landscaping variable studied at the destination location of sewo settlers was the type of land, showing the results that all the sites were on the land of the brown-brown mediteran complex-Regosol-Liosol or KMC. This type of land is very suitable as an agricultural area including systematic rice farming. The last landscape variable is the river, showing that the eight sites of the 14thcentury Soppeng kingdom were always in locations near the river with shallow groundwater conditions.

The identification of landscape variables, especially the height of the place, marbles, soil type, or distance from the river shows that the Sewo exodus is indeed targeting ideal locations for rice farming. This phenomenon illustrates that before leaving Sewo, the exodus had already had an understanding of the insights of rice farming. In addition, the exodus has also known well the potential and territory of the Soppeng region.

Lontarak attoriolonna Soppeng did not mention the exact number of years of the spread of sewo exodus, but the episode can be placed before the appearance of Tomanurung (a figure who descended from the sky) in Sekkanyili who would later become the first king of Soppeng. If so, we can put such exodus episodes in the 12th and 13th centuries. For about a century after arriving in the lowlands, the exodus that would later become the buffer toponym of the Kingdom of Soppeng Rilau experienced a surplus of rice. Interesting to listen to the contract of the matoa or the leader of each old toponim with Tomanurung ri Sekkanyili (One who came from the sky in Sekkanyili) as firmly described in Lontara Attoriolonna Soppeng as follows:

Then 60 Matoa left. When they met Tomanurung, Matoa Ujung, Botto, and Bila said, "We came here, blessed O, to pity [us]. Don't disappear. We made you our master. You protect our plants from birds so we don't lack food. You covered us so it wasn't cold. You tie our rice so we are not empty and you lead us far or near. If you reject our wives and children, we will reject them too."

Interesting to look at the contract of the matoa with Tomanurung ri Sekkanyili. In the century as there is no mentionable exact time mentioned in the chronicle or chronicle Setting the time of spread at the Sewo exodus estimated Time of exodus In the same phase (13th century), Tinco in $760 \pm 30 \mathrm{BP}$ (between 1219-1284)

Now, we need to realize that the disclosure of South Sulawesi's cultural history has progressed rapidly. If previously, the historical work of South Sulawesi was more based on lagaligo epics and ancient manuscripts written by educated nobles, in the last three decades, the use of archaeological evidence, especially foreign ceramic fragments imported from other countries has had a very encouraging impact. We have come out of a stagnation of perspective as evidenced by collaborative work between historians, philologists, linguistics, ethnographers and archaeology. The result is the birth of several multi- and trans perspective works so that the period of the 13th and 
14th centuries (protohistory of South Sulawesi) which was initially dark began to unfold little by little. The collaborative works we refer to such as the results of oxis project research in Luwu and China, by Kallupa et al., [1] ; Fadillah et al., [6]; Nayati, [7]; Bougas, and Bulbeck, [8]. Such a collaborative working model has promising prospects in the future. We have no choice but to refer to these prolific works to illustrate"where are we know" about the cultural history of South Sulawesi. Once the picture is formed, we will put the novelty of this book and that is what we mean as the importance of soppeng petroglyph in a broader context.

Speaking of the history of the Bugis, two perspectives are widely referenced by South Sulawesi researchers so far, namely the perspective proposed by Christian Pelras [9] in his most important work entitled The Bugis (1996) which has been translated into Indonesian in the book entitled Bugis Man (2006) and Caldwell \& Bulbeck [10] which was published in an article entitled Land of Iron; The historical archaeology of Luwu and the Cenrana valley. The difference between the two perspectives above mainly lies in his description of the Bugis culture that flourished in the years 1100 to 1300 . Pelras [9] mentions the Early Bugis culture or Galigo Age that lasted between 1100-1200 and 1300 was the Era of Anarchy or the era of chaos (Bugis: sianre bale)that ended or greatly modified social and political institutions and practices in the Galigo Era.

On the other hand, Caldwell \& Bulbeck [10] refers to "the year 1200 as the Proto History Period marked by the start of the Bugis settlement on the west coast of Lake Tempe, the development of trade relations with Java through the southern coast of Makassar, the increasing demand for rice as merchandise that stimulated the expansion and intensification of agriculture and forest clearing, South Sulawesi was incorporated into a trade network focused on India and China through the the northeast coast of Java and the Southern Philippines and the beginning of imports of Chinese and Southeast Asian ceramics, in 1300 referred to as the Early Historical Period Marked by the beginning of the Bugis settlement in Malangke, the Bugis began to unify the Luwu region through trade alliances. Intensification of agriculture in the Cenrana and Soppeng valleys led to political centralization. The rise of the first kingdom; important cultural influences of SingosariMajapahit; The ruler of Luwu adopted JavaneseSanskrit titles..." [10].

Our results are based on archaeological analysis and its association with foreign ceramic finds, the absolute dated $\mathrm{C} 14$ results, dozens of megalith monuments and hundreds of stone chunks of agricultural processing tools that show that the cultural conditions of Soppeng in the 1300s seem like an uphill graph with rice surplus and an increasing number of populations that increasingly require unification due to the insistence of competition with neighbouring forces or communities. another complex. The phenomenon of the emergence of Tomanurung Sekkanyili who became the first king of Soppeng Riaja can indeed be considered a solving problem towards the union of all equal wanuwa, but cannot be read as an age of anarchy as proposed by Pelras [9]. We prefer to refer to the unification of soppeng power as the response of the established peasant community that occupied ancient wanuwawanuwa to maintain its surplusachievements. In other words, our results are more in line with the proposed model of Caldwell \& Bulbeck [10] which calls the concept of his proposal a new chronology for South Sulawesi.

Archaeological data very firmly provide evidence that the Kingdom of Soppeng in the 13th and 14th centuries developed rapidly and can be considered the most important period in the history of the Kingdom of Soppeng. There can be no trade-in imported ceramics that is very rife ranging from coastal areas to the interior of Soppeng. Trade in expensive goods must take place in areas that are surplus, not in areas where people are in chaos. Although the evidence rejects the Age of Anarchy Pelras ethnographic record [9] about Bugis astronomy and its constellation treasury is very following our findings although there are slight differences in mention, for example, the constellation Tekkosorong turned out to be called rakkala by the Soppeng people which both mean plows.

Summarizing this discussion, this research's contribution to the history of the Bugis was the discovery of the Sewo site and the buffer site of the Pre-Islamic Kingdom of Soppeng which contained information about the insights of knowledge underlying the momentum of rice farming intensification that triggered the rice surplus at that time. The intended intensification of agriculture is the transition from moving into more advanced processing. More specifically of this process are the concentration on rice crops at the expense of other food crops, and the expansion of wet rice farming (Macknight, 1983).

\section{CONCLUSION}

Changes in the use of landscapes in the protohistorical period in the Kingdom of Soppeng Riaja or South Sulawesi is a theme that is still rarely discussed. In this study, we managed to uncover that 
the change in the use of the proto-historical landscape is the foundation that established the emergence of historical civilization, at least in Soppeng Riaja. The change in mindset from utilizing hilly land to flat land use for systematic rice farming has triggered surpluses and increasingly complex social, economic and cultural life. Rice surpluses allow for exchange and trade that has implications for the intensifying relationship between local cultures and outside cultures. Evidence of thousands of imported ceramics from the Soppeng kingdom supports this argument, although the kingdom of Soppeng is known as a kingdom located in the interior. In the context of South Sulawesi, this study shows that flat landscape occupancy is the most important point in the history of rice farming or the growth of historical civilization in South Sulawesi.

\section{REFERENCES}

[1] Kallupa, Bahru, David Bulbeck, Ian Caldwell, Iwan Sumantri and Karaeng Demmanari (1989). 'Survey pusat kerajaan Soppeng 1100-1986: Final report to the Australian Myer Foundation'. Canberra. [Diterbitkan secara pribadi.]

[2] Nur, Muhammad. (2015). Nilai Penting Kawasan Depresi Walennae, Kabupaten Soppeng, Sulawesi Selatan. Jurnal Konservasi Cagar Budaya Borobudur no. 2. hal: 34-42.

[3] Harjdowinegoro, Sarwono. (2003). Ilmu Tanah. Akademika Pressindo: Jakarta.

[4] Kartasopoetra, Ir. A.G., et al., (2005). Teknologi Konservasi Tanah dan Air, Rineka Cipta: Jakarta.

[5] Hasanuddin. (2015). Kebudayaan megalitik di Sulawesi Selatan dan hubungannya dengan Asia Tenggara. $\mathrm{PhD}$ thesis, Universiti Sains Malaysia, Penang.

[6] Fadillah. Moh. Ali, et al., (2020). Inti Konfederasi Wajo: Survey Arkeologi di Tosora, Cinnotabi dan Lamasewanua. Jurnal Walennae. Jurnal Walennae, 18 (2), 131-148.

[7] Nayati, Widya, 2005. Social Dynamics and Local Trading Pattern in the Bantaeng Region, South Sulawesi (Indonesia) circa 17th century. Disertasi Doktor. National University of Singapore.

[8] Bougas, W.A., (1998), "Bantayan: An Early Makassarese Kingdom 1200-1600 AD”, Archipel 55, pp. 83-123.

[9] Pelras, Christian. (1996). The Bugis. Oxford: Blackwell.
[10] Bulbeck, David and Ian Caldwell (2000). Land of iron: The historical archaeology of Luwu and the Cenrana valley. Results of the Origin of Complex Society in South Sulawesi Project (OXIS). Hull: Centre for South-East Asian Studies, University of Hull. 